\author{
Ye.M. Suleimen ${ }^{1,2 *}$, E.V. Zheludeva ${ }^{3}$, A. Bazarkhankyzy ${ }^{1}$, Zh.B. Tekebayeva ${ }^{1}$, \\ Buddha Bahadur Basnet ${ }^{4}$, S.K. Nayekova ${ }^{1}$, Z.S. Sarmurzina ${ }^{1}$ \\ ${ }^{1}$ Republican Collection of Microorganisms, Nur-Sultan, Kazakhstan; \\ ${ }^{2}$ Kokshetau University, Kokshetau, Kazakhstan; \\ ${ }^{3}$ Institute of Biological Problems of the North, Far-Eastern Branch of Russian Academy of Sciences, Magadan, Russia; \\ ${ }^{4}$ Nepal Academy of Science and Technology (NAST), Khumaltar, Lalitpur, Nepal \\ *Corresponding author: syerlan75@yandex.ru
}

\title{
The isolation of fungi from lichens of the Magadan region and biological activity of their extracts
}

\begin{abstract}
The study aims to isolate fungi from lichens of the Magadan region (Russia) and evaluate their antibacterial and antifungal activity. Fourteen species of lichen from the Magadan region (Russia) were selected for the study. Antibacterial activity was determined based on gram-positive (Staphylococcus aureus) and gramnegative bacteria (Escherichia coli). Antifungal activity was identified by using strains of Aspergillus terreus and Candida albicans. According to the results of the study, fungi isolated from lichens Peltigera leucophlebia (CD), Hypogymnia sachalinensis (CD) showed antifungal activity, and fungi from Peltigera leucophlebia (CD), Peltigera aphthosa (CD), Melanohalea olivacea (PDA, CD), displayed antibacterial activity. As a result of studying the biological activity, the fungi isolated from the lichen Peltigera leucophlebia $(\mathrm{CD})$ have both antibacterial and antifungal activity.
\end{abstract}

Keywords: lichens, Magadan region, fungi, antibacterial activity, antifungal activity.

\section{Introduction}

Lichens are complex symbiotic associations between a fungus (mycobiont) and an alga (photobiont) and used in traditional medicine for various diseases due to the presence of several bioactive compounds [1]. Lichen compounds can be arbitrarily divided into two groups: primary and secondary compounds. Primary lichen compounds have structural functions and are involved in cell metabolism.

Secondary lichen compounds are characterized by acid properties, such as lichen acids $[2,3]$. Each lichen species has its own set of lichen acids, which generally gives qualitative reactions enabling the lichen species to be discriminated against. Many lichen species contain atranorin, usnic acid, lecanoric acid, salazinic acid, lobar acid, and other acids [4]. Lichen acids are essential to identify the lichens, and could be used as natural antibiotics $[5,6]$. Therefore, the bioactive compounds from lichens have various biopharmaceutical applications as antimicrobial, antioxidant and cytotoxic agents, which can be the basis for the development of new antibiotics $[7,8]$.

\section{Experimental}

\section{Lichen materials}

Fourteen types of lichens: Flavocetraria nivalis (L.) Kärnefelt et A. Thell, Cetraria laevigata Rass., Umbilicaria hyperborea (Ach.) Hoffm., Melanohalea olivacea (L.) O. Blanco, A. Crespo, Divakar, Essl., D. Hawksw. et Lumbsch, Cladonia ecmocyna Leight, Flavocetraria cucullata (Bellardi) Kärnefelt et A. Thell, Cetraria islandica (L.) Ach., Cladonia uncialis (L.) Wigg., Vulpicida pinastri (Scop.) J.-E. Mattsson, Peltigera aphthosa (L.) Willd., Cladonia stellaris (Opiz) Pouzar et Vězda, Vulpicida juniperinus (L.) J.-E. Mattsson et M.J. Lai, Peltigera leucophlebia (Nyl.) Gyeln., Hypogymnia sachalinensis Tchabanenko et McCune, were collected in October, 2019, in the Magadan region (Russian Federation) and identified by Dr. E.V. Zheludeva (Institute of Biological Problems of the North, Far-Eastern Branch of the Russian Academy of Sciences) (Fig. 1). 


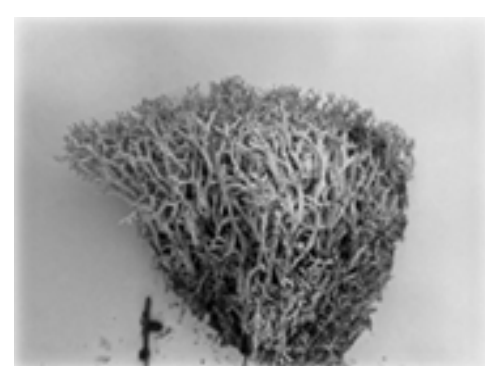

Cladonia uncialis

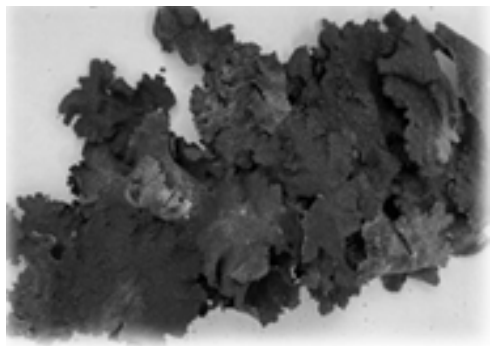

Umbilicaria hyperborea

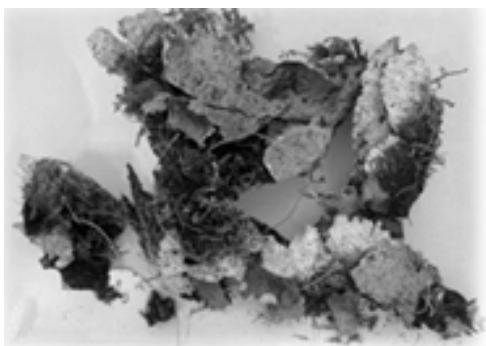

Peltigera leucophlebia

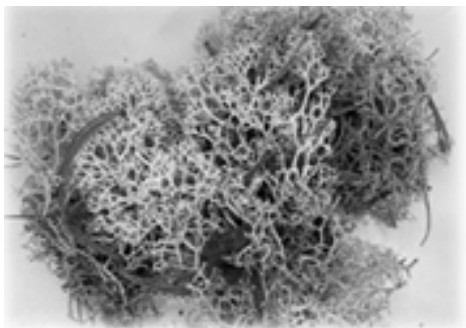

Cladonia stellaris

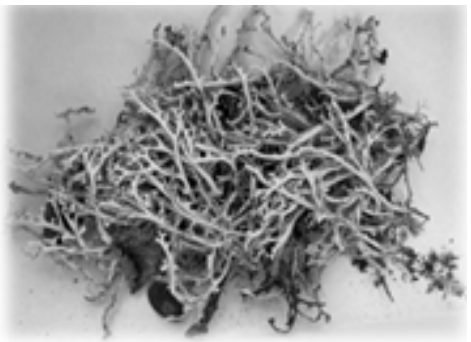

Flavocetraria cucullata

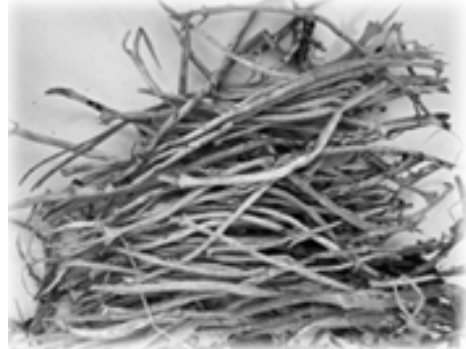

Cladonia ecmocyna

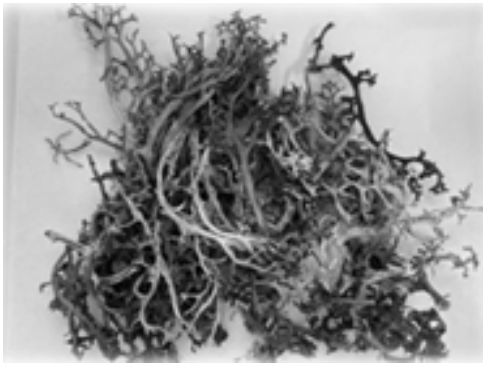

Cetraria islandica

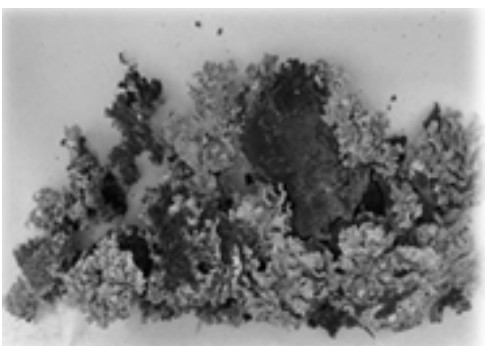

Vulpicida pinastri

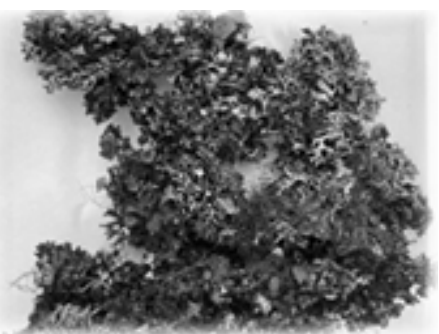

Hypogymnia sachaliensis

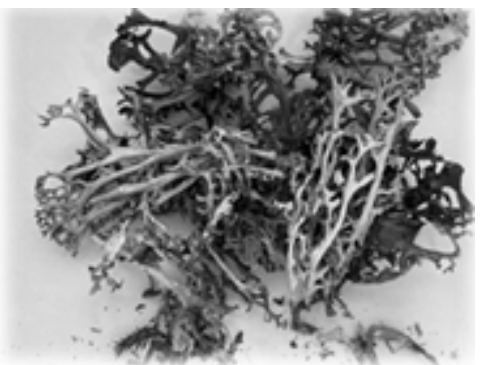

Cetraria islandica

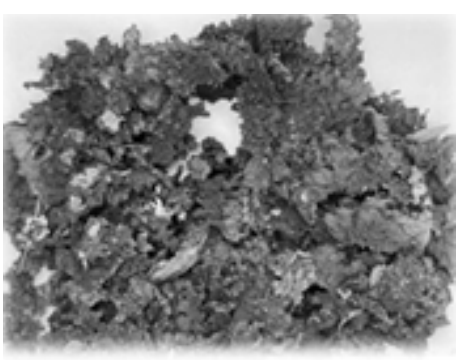

Melanohalea olivacea

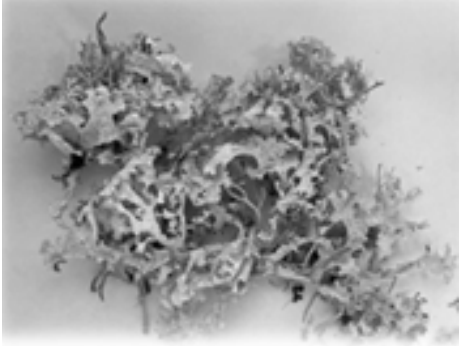

Flavocetraria nivalis

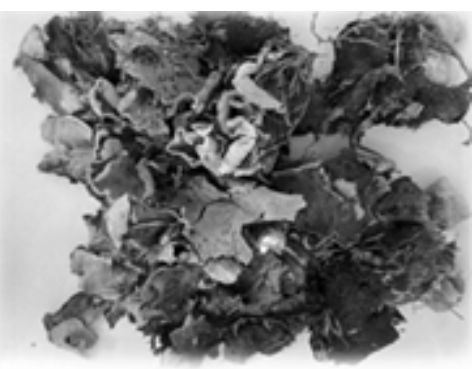

Peltigera aphthosa

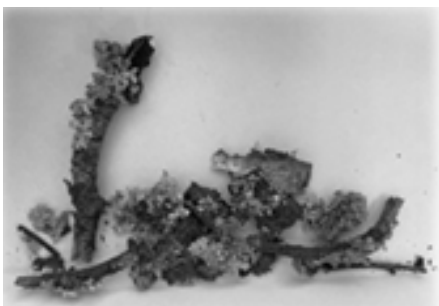

Vulpicida juniperinus

Figure 1. Lichens of the Magadan region (Russia)

Growth nutrient medium

Potato Dextrose Agar (PDA), Czapek DOX Agar (CD), Potato Dextrose Broth (PDB), and Czapek DOX Broth (CDB) were used. 


\section{Method of isolation of fungi from lichens}

Lichen were cut into small pieces (about $0.5 \times 0.5 \times 0.5 \mathrm{~cm}$ ), washed with a chemical solution (distilled water, $96 \% \mathrm{EtOH}, 70 \% \mathrm{EtOH}, 1 \% \mathrm{NaClO}$ ). A Petri dish with an antibiotic (streptomycin) was divided into 4 sectors; one fragment of lichen was added to each sector. Samples were incubated in a darkened place at room temperature for 7-10 days. The process was repeated 3 times, after which a culture of pure fungi was obtained. A pure identified fungi culture, grown in a solid medium (PDA, CD), was placed in a flask with a liquid medium (PDB, $\mathrm{CDB}$ ) to produce biomass. During cultivation at the room temperature in dark place for 7-10 days, it was used the Biosan PSU-20i Orbital Shaker at $110 \mathrm{rpm}$.

\section{Antibacterial activity}

The antagonistic activity of lichen-fungi was determined by diffusion into agar by the diameter of the zone of absence of the growth of opportunistic cultures: Staphylococcus aureus (B-RKM 0470) and Escherichia coli (B-RKM 0447), provided by the Central Museum of the Republican Collection of Microorganisms (Nur-Sultan, Kazakhstan). For this purpose, medium MPA (meat-peptone agar, Nutrient agar + Meat extract, $5 \mathrm{~g} / \mathrm{l}$ ) is used. The pathogenic cultures in the form of suspensions of cells in the amount of $1 \mathrm{bln} / \mathrm{ml}$ (for bacterial turbidity standard of 0.5 ) were applied on the surface of the Petri dish, rub thoroughly with a spatula over the surface of the medium, then cut out holes with a drill diameter of $10 \mathrm{~mm}$ and filled them with the investigated cultures $(0.1 \mathrm{ml})$. The zones of inhibition were measured after 24 hours, and the results were presented without deducting the diameter of the whole zone. The antagonistic activity was considered zero at the width of the zone of absence of test strains up to $1.0 \mathrm{~mm}$, low - at $1.1-4.9 \mathrm{~mm}$, medium — at 5.0-8.9 $\mathrm{mm}$, high — at $9.0 \mathrm{~mm}$ or more $[9,10]$.

\section{Antifungal activity}

Antifungal activity of fungi extract was identified using two test strains: Aspergillus terreus (B-RKM 0697), Candida albicans (B-RKM 0475) provided by the Central Museum of the Republican Collection of Microorganisms (Nur-Sultan, Kazakhstan). The Petri dishes with PDA and CD media were prepared and waited until solidification and suspension in the amount of $1 \mathrm{bln} / \mathrm{ml}$ (for bacterial turbidity standard of 0.5), were placed on Petri dishes and rub thoroughly with a spatula over the surface of the medium. Then, the holes with diameter of $10 \mathrm{~mm}$ were drilled and filled with the cultures organisms $(0.1 \mathrm{ml})$. After 48 hours of incubation, the inhibition zones were measured.

\section{Fermentation of fungi}

Fermentation was carried out in conical flasks $(250 \mathrm{ml})$, each containing $60 \mathrm{~g}$ of rice and wheat. Distilled water $(60 \mathrm{ml})$ was added to each flask and autoclaved at $15{ }^{\circ} \mathrm{C}$ for 30 minutes. After cooling to room temperature, $50-100 \mathrm{ml}$ of pure culture suspension isolated from lichen was poured into the flask. Cultivation was carried out at room temperature for 25 days, in a dark place.

\section{Results and Discussions}

\section{Mycelial cultures}

Fungi isolated from lichens Cetraria islandica, Cladonia uncialis, Flavocetraria nivalis did not grow after the first sowing on nutrient media (PDA, CD) with the antibiotic streptomycin, other fungi from the samples, such as Peltigera aphthosa, Cladonia stellaris, Vulpicida juniperinus, Umbilicaria hyperborea, Flavocetraria cucullata did not grow on PDA, but showed a good growth on CD (Fig. 2).

In the case of Peltigera leucophlebia, Vulpicida pinastri Hypogymnia sachalinensis, and Melanohalea olivacea, mycelium growth was observed on two nutrient media. The fungi were actively growing after the first sowing. After each seed incubation, the mycelium turned from light to dark. The growth of Cladonia ecmocyna is very slow in nutrient media, its color is light, and has acquired a convex shape. Fungi isolated from the lichen Cetraria laevigata showed excellent growth on the PDA medium; the shape is uniform, the color is white.

Mycelium growth was checked every week, and after one month, we received pure fungi. Each fungus demonstrated a different growth rate and pigmentation. 


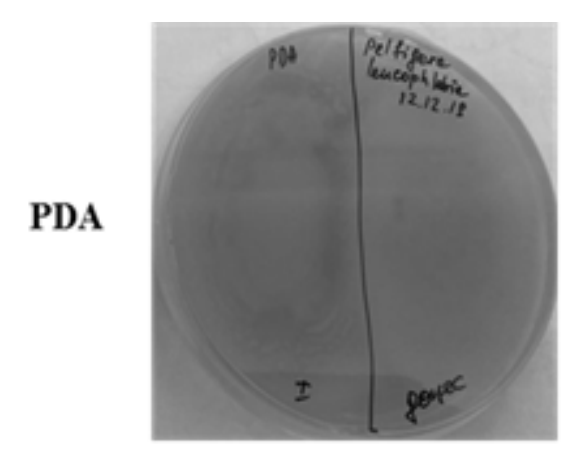

Peltigera leucophlebia

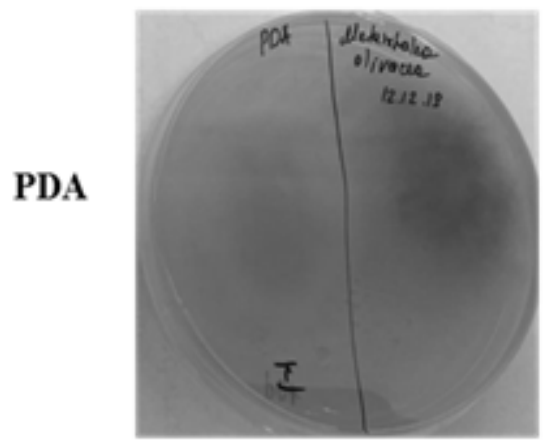

Melanohalea olivacea

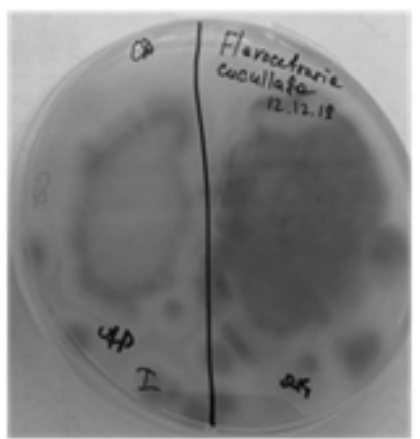

Flavocetraria nivalis

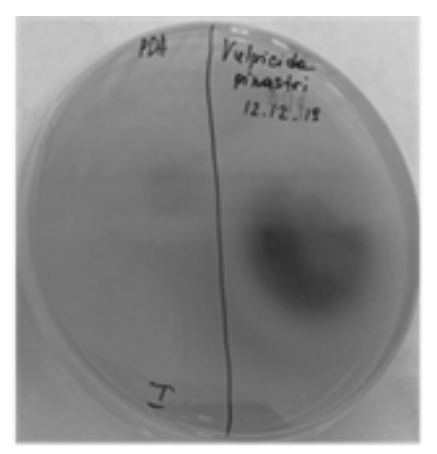

Vulpicida pinastri

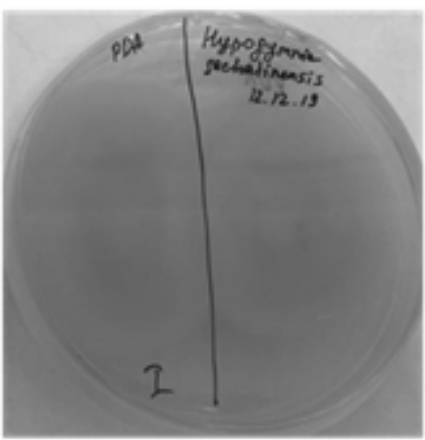

Hypogymnia sachalinensis

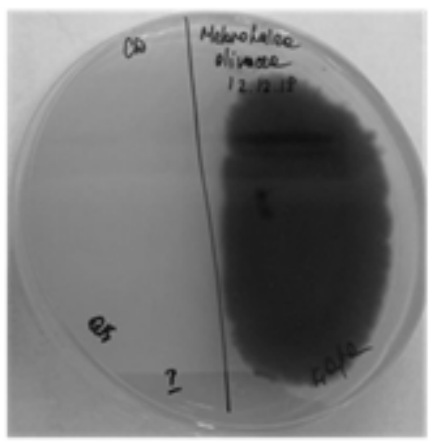

Melanohalea olivacea

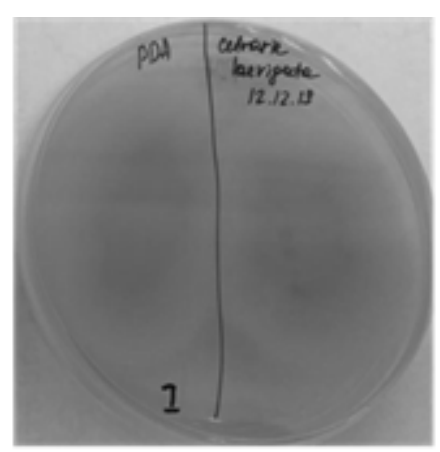

Cetraria laevigata

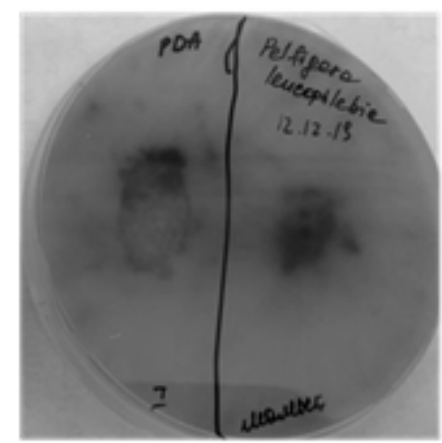

Peltigera leucophlebia

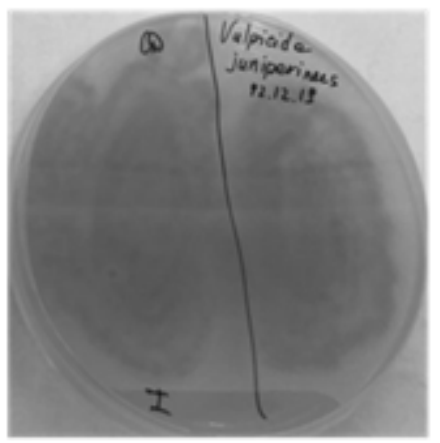

Vulpicida juniperinus

Figure 2. The process of fungi isolation from lichens of the Magadan region in two nutrient media PDA, CD

\section{Antibacterial activity}

The antibacterial activity of fungi isolated from lichens of the Magadan region was evaluated using agar diffusion method. The diffusion method in the agar provides information on the resistance of fungi material extracts to various microorganisms [11]. Fungi extracts were tested with gram-positive and gram-negative strains. Vulpicida pinastri, Cladonia stellaris, Hypogymnia sachalinensis, Vulpicida juniperinus, Cetraria laevigata, Umbilicaria hyperborea, Flavocetraria cucullata did not show antimicrobial activity on both test strains. Fungi from Peltigera leucophlebia (CD), Peltigera aphthosa (CD), Melanohalea olivacea (PDA, $\mathrm{CD})$ showed an antimicrobial activity (average $-5.0-8.9 \mathrm{~mm}$ ). According to experimental data, it is demonstrated that the activity of lichens is also affected by nutrient media.

\section{Antifungal activity}

Antifungal activity was determined on a solid medium based on a test strain of Aspergillus terreus (B-RKM 0697), Candida albicans (B-RKM 0475). This study illustrated relatively high activity of fungi from Peltigera leucophlebia (CD). Fungi isolated from lichens suppressed the growth of test strains, which indicates antifungal activity. At that time, only the growth of the test strain was observed in other samples. 


\title{
Conclusions
}

It was found that fungi isolated from lichens of the Magadan region have a biological activity. Fungi isolated from Peltigera leucophlebia (CD), Hypogymnia sachalinensis (CD) showed antifungal activity on Aspergillus terreus, Candida albicans.

Fungi isolated from Peltigera leucophlebia (CD), Peltigera aphthosa (CD), Melanohalea olivacea (PDA, CD) have activity against gram-positive (Staphylococcus aureus), and gram-negative bacteria (Escherichia coli). These experiments make it possible to study further in-depth their other biological, physical, and chemical properties.

\section{Acknowledgment}

This research was funded by the Science Committee of the Ministry of Education and Science of the Republic of Kazakhstan (Grant "Creation and replenishment of the collection of industrially valuable microorganisms, study and preservation of their biological diversity for the needs of biotechnology, medicine and agriculture").

\section{References}

1 Mitrovic T. Lichens as source of versatile bioactive compounds / T. Mitrovic, S. Stamenkovic, V. Cvetkovic, M. Nikolic, S. Tosic, D. Stolcic // Biologica Nyssana. - 2011. - Vol. 2, No. 1. - P. 1-6.

2 Boustie J. Bioactive lichen metabolites: alpine habitats as an untapped source / J. Boustie, S. Tomasi, M. Grube // Phytochemistry Reviews. - 2011. - No. 10. - P. 287-307.

3 Yamamoto Y. Lichen Substances and Their Biological Activities / Y. Yamamoto, K. Hara, H. Kawakami, M. Komine // Recent Advances in Lichenology. - 2015. - No. 2. - P. 181-189.

4 Gomes-Serranillos M.P. Parmeliaceae family: phytochemistry, pharmacological potential and phylogenetic features / M.P. Gomes-Serranillos, C. Fernandez-Moriano, E. Gonzalez-Burgos, P.K. Divakar, A. Crespo // RSC Advances. — 2014. — No. 4. - P. 59017-59047.

5 Lauterwein M. In vitro activities of the lichen secondary metabolites vulpinic acid, (+)-usnic acid, and (-)-usnic acid against aerobic and anaerobic microorganisms / M. Lauterwein, M. Oethinger, K. Belsner, T. Peters, R. Marre // Antimicrobial Agents and Chemotherapy. - 1995. - No. 11. - P. 2541-2543.

6 Shrestha G. Lichens: a promising source of antibiotic and anticancer drugs / G. Shrestha, L. Larry, St. Clair // Phytochemistry Reviews. - 2013. - No. 12. - P. 229-244.

7 Zambare V.P. Biopharmaceutical potential of lichens / V.P. Zambare, L.P. Christopher // Pharmaceutical Biology. - 2012. - Vol. 50, Issue 6. - P. 778-798.

8 Basnet B.B. Diversity of anti-cancer and anti-microbial compounds from lichen and lichen-derived fungi: A systematic review (1985-2017) / B.B. Basnet, L. Liu, H. Liu, Ye.M. Suleimen // Current Organic Chemistry. — 2018. — Vol. 22. — P. 24872500. https://doi.org/10.2174/1385272822666181109110813

9 Практикум по микробиологии. - М.: Академия, 2005. - 119 с.

10 Скородумов Д.И. Микробиологическая диагностика бактериальных болезней животных / Д.И. Скородумов, В.В. Субботин, М.А. Стдоров, Т.С. Костенко. - М.: Изограф, 2005. - 656 с.

11 Bauer A.W. Antibiotic susceptibility testing by a standardized single disk method / A.W. Bauer, W.M. Kirby, J.C. Sherris, M. Turck // American Journal of Clinical Pathology. — 1966. — P. 493-496.

\author{
Е.М. Сулейман, Е.В. Желудева, А. Базарханкызы, Ж.Б. Текеубаева, \\ Будда Бахадур Башнет, С.К. Наекова, 3.С. Сармурзина
}

\section{Магадан облысы қыналарынан саңырауқұлақтардың алынуы және олардың ферментативті сығындыларының биологиялық белсенділігі}

\begin{abstract}
Зерттеу жұмысының мақсаты - Магадан облысының (Ресей) қыналарынан саңырауқұлақтарды бөліп алу және олардың микробқа, саңырауқұлаққақарсы белсенділігін анықтау. Зерттеу нысаны ретінде Магадан облысы қыналарының 14 түрі алынды. Микробқақарсы белсенділігі грамоң (Staphylococcus aureus) және грамтеріс бактериялар (Escherichia coli) негізінде анықталды. Саңырауқұлаққақарсы белсенділік Aspergillus terreus және Candida albicans штамдары арқылы табылды. Зерттеу нәтижелері бойынша Peltigera leucophlebia (CD), Hypogymnia sachalinensis (CD) қыналарынан бөлінген үлгілер саңырауқұлаққақарсы, ал Peltigera leucophlebia (CD), Peltigera aphthosa (CD), Melanohalea olivacea (PDA, СД) бөлініп алынған саңырауқұлақтар микробқақарсы белсенділік көрсетті. Биологиялық
\end{abstract}


белсенділікті зерттеу нәтижесінде Peltigera leucophlebia (CD) бөлініп алынған саңырауқұлақ микробқа және саңырауқұлаққақарсы белсенділікке ие болды.

Кілm сөздер: қыналар, Магадан облысы, саңырауқұлақтар, микробқақарсы белсенділік, фунгальғақарсы белсенділік.

\author{
Е.М. Сулейман, Е.В. Желудева, А. Базарханкызы, Ж.Б. Текеубаева, \\ Будда Бахадур Башнет, С.К. Наекова, 3.С. Сармурзина
}

\title{
Выделение грибов из лишайников Магаданской области и биологическая активность их ферментативных экстрактов
}

\begin{abstract}
Цель данного исследования - выделить грибы из лишайников Магаданской области (Россия) и оценить их антимикробную и противогрибковую активность. Для исследования были отобраны 14 видов лишайников. Противомикробную активность определяли на граммположительных (Staphylococcus aureus) и граммотрицательных (Escherichia coli) бактериях. Противогрибковую активность выявляли с использованием штаммов микроскопических грибов Aspergillus terreus и Candida albicans. Согласно результатам исследования, образцы, выделенные из лишайников Peltigera leucophlebia (CD), Hypogymnia sachalinensis (CD), показали противомикробную активность, а у образцов из Peltigera leucophlebia (CD), Peltigera aphthosa (CD), Melanohalea olivacea (PDA, CD) наблюдалась антимикробная активность. В результате изучения биологической активности установлено, что гриб, выделенный из лишайника Peltigera leucophlebia (CD), обладает антимикробной и противогрибковой активностью.
\end{abstract}

Ключевые слова: лишайники, Магаданская область, грибы, антимикробная активность, антифунгальная активность.

\section{References}

1 Mitrovic, T., Stamenkovic, S., Cvetkovic, V., Nikolic, M., Tosic, S., \& Stolcic, D. (2011). Lichens as source of versatile bioactive compounds. Biologica Nyssana, 2, 1, 1-6.

2 Boustie, J., Tomasi, S., \& Grube, M. (2011). Bioactive lichen metabolites: alpine habitats as an untapped source. Phytochemistry Reviews, 10, 287-307.

3 Yamamoto, Y., Hara, K., Kawakami, H., \& Komine, M. (2015). Lichen Substances and Their Biological Activities. Recent Advances in Lichenology, 2, 181-189.

4 Gomes-Serranillos, M.P., Fernandez-Moriano, C., Gonzalez-Burgos, E., Divakar, P.K., \& Crespo, A. (2014). Parmeliaceae family: phytochemistry, pharmacological potential and phylogenetic features. RSC Advances, 4, 59017-59047.

5 Lauterwein, M., Oethinger, M., Belsner, K., Peters, T., \& Marre, R. (1995). In vitro activities of the lichen secondary metabolites vulpinic acid, (+)-usnic acid, and (-)-usnic acid against aerobic and anaerobic microorganisms. Antimicrobial Agents and Chemotherapy, 11, 2541-2543.

6 Shrestha, G., Larry, L., \& Clair, St. (2013). Lichens: a promising source of antibiotic and anticancer drugs. Phytochemistry Reviews, 12, 229-244.

7 Zambare, V.P., \& Christopher, L.P. (2012). Biopharmaceutical potential of lichens. Pharmaceutical Biology, 50, 6, 778-798.

8 Basnet, B.B., Liu, L., Liu, H., \& Suleimen, Ye.M. (2018). Diversity of anti-cancer and anti-microbial compounds from lichen and lichen-derived fungi: A systematic review (1985-2017). Current Organic Chemistry, 22, $2487-2500$. https://doi.org/10.2174/1385272822666181109110813

9 Praktikum po mikrobiologii [Microbiology Workshop]. (2005). Moscow [in Russian].

10 Skorodumov, D.I., Subbotin, V.V., Sidorov, M.A., \& Kostenko, T.S. (2005). Mikrobiologicheskaia diagnostika bakterialnykh boleznei zhivotnykh [Microbiological diagnosis of animal bacterial diseases]. Moscow: Izograph [in Russian].

11 Bauer, A.W., Sherris, J.C., \& Turck, M. (1966). Antibiotic susceptibility testing by a standardized single disk method. American Journal of Clinical Pathology, 493-496. 